\section{Prevalence of tir gene subtypes in Escherichia coll isolates from pigs}

\author{
Y. HA, S. K. HA, Y. H. LEE, D. KIM, S. ChAE, \\ C. H. KIM, K. K. AHN, O. KıM, C. CHAE
}

ATTACHING and effacing Escherichia coli (AEEC) are characterised by their capacity to infect intestinal epithelial cells, resulting in attaching and effacing $(\mathrm{AE})$ lesions. AE histopathology is characterised by intimate adherence of the bacteria to enterocytes and disruption of the underlying cytoskeleton (Moon and others 1983). A chromosomal gene, eae, encodes the protein intimin, which contributes to this intimate adherence (Jerse and others 1990, Jerse and Kaper 1991, Zhu and others 1994). The tir gene encodes the intimin receptor (Tir), which is translocated into the cytoplasm of the host where it is phosphorylated and then incorporated into the host cell membrane (Kenny and others 1997).

The eae gene shows high conservation in the N-terminal region, which encodes the region of the intimin protein that binds to Tir, but there is variability in the last C-terminal 280 amino acids between eae gene subtypes (Frankel and others 1994). On the basis of deduced amino acid sequences and PCR analysis, at least 16 subtypes of eae have been described (Agin and Wolf 1997, Adu-Bobie and others 1998, China and others 1999, Oswald and others 2000, Zhang and others 2002, Garrido and others 2006). Among these subtypes, the $e a e_{\beta}$ gene was found to be the most common subtype among isolates of AEEC from pigs with diarrhoea, followed by eae, $e a e_{\varepsilon}$, and $e a e_{\xi}$ (Ha and others 2004). The tir gene has highly conserved central regions that encode the region that binds to intimin, and variable regions outside of these central intiminbinding regions (Liu and others 2002, Nielsen and Andersen 2003). On the basis of deduced amino acid sequences and PCR analysis, at least four subtypes of tir have been identified: $\alpha$, $\beta, \gamma$, and $\theta$ (Goffaux and others 2000, Nielsen and Andersen 2003). To the best of the authors' knowledge, there have been no reports of subtypes of $t i r$ in isolates of AEEC from pigs. This short communication describes a study in which PCR was used to determine the subtypes of tir present in AEEC isolated from pigs with diarrhoea in the Republic of Korea.

A total of 59 AEEC isolates were analysed. Thirty-eight of the isolates were identified as AEEC out of $707 \mathrm{E}$ coli isolates from diarrhoeic preweaned pigs, and 21 were identified as AEEC out of 480 isolates from diarrhoeic postweaned pigs. The eae gene subtypes of the isolates were identified in a previous study by Ha and others (2004). All the farms were farrow-to-finish operations and nine farms were using an all-in/all-out rearing system. Fifty AEEC were isolated from Large White $\times$ Duroc crossbred pigs and nine were isolated from pigs of unknown breed. Among the 38 isolates from preweaned pigs, 12 were from Kyounggi province, eight were from Chungcheung province, seven were from Cholla province and 11 were from Kyoungsang province. Among the isolates from postweaned pigs, six were from Kyounggi province, five were from Chungcheung province, four were from Cholla province and six were from Kyoungsang province.

Pigs were submitted alive or dead for diagnosis of the cause of diarrhoea; those submitted alive were sedated by an intravenous injection of sodium pentobarbital, stunned electrically and then bled out as previously described (Anon 2001). Immediately after euthanasia or, for pigs submitted dead, immediately upon receipt, specimens of ileal content were collected for bacteriological culture on 5 per cent sheep blood agar and Tergitol-7 agar (Difco Laboratories). The

\begin{tabular}{|c|c|c|c|}
\hline Target gene & Primer sequence $5^{\prime}-3^{\prime}$ & Amplicon (bp) & Reference \\
\hline \multirow{2}{*}{$t i r_{\alpha}$} & САGСCTGCCACTTACCTTCACA & & \\
\hline & СGСТААССТССАААССАТТ & 342 & China and others (1999) \\
\hline \multirow[t]{2}{*}{$\operatorname{tir}_{\beta}$} & CAGCCTGCCACTTACCTTCACA & & \\
\hline & GATTTTTTCCCTCGCCACTA & 560 & China and others (1999) \\
\hline \multirow[t]{2}{*}{$t i r_{\gamma}$} & САGСCTGCCACTTACCTTCACA & & \\
\hline & GTCGGCAGTTTCAGTTTCAC & 781 & China and others (1999) \\
\hline \multirow[t]{2}{*}{$\operatorname{tir}_{\theta}$} & CTAGCGCAGTGGTTAATCCATATG & & \\
\hline & ATTCCCTGAGAAATTTTGAATGACG & 137 & Nielsen and Andersen (2003) \\
\hline
\end{tabular}

bp Base pairs

colony characteristics of isolates were noted, including haemolysis on blood agar and texture (smooth, rough, mucoid) on Tergitol-7 agar, for routine diagnostic procedures. Infections were considered to be potentially dual or multiple when colonies with different haemolytic patterns or morphology were observed on one plate.

For each culture, all isolates with different phenotypes were selected for PCR analysis. PCR for tir gene subtypes was carried out as previously described by China and others (1999) and Nielsen and Andersen (2003) with the primers shown in Table 1. PCR for the Shiga toxin gene was also carried out as previously described by Kong and others (1999). The PCRs were performed in triplicate. Control DNA from reference strains was included in each reaction.

The primer pair for each tir subtype yielded PCR products of the expected size for the control strains and field isolates. The results of the analysis of tir gene subtypes are shown in Table 2. None of the AEEC isolates studied carried the gene for Shiga toxin.

The results of this study show the presence of various combinations of eae and tir subtype genes. The combination of $e a e_{\gamma}$ and $t i r_{\gamma}$ is the most common in E coli isolated from human beings, while the pathotype $e a e_{\beta}$ and $t i r_{\beta}$, seems to be most frequently associated with diarrhoea in calves (China and others 1999). In these pigs, the $e a e_{\beta}$ gene was associated with the $\operatorname{tir}_{\theta}$ gene in 14 of 59 isolates. Homologous combinations were also present: $e a e_{\beta}$ with $t_{i r}$ in two isolates and $e a e_{\gamma}$ with $t i r_{\gamma}$ in three isolates. Four subtypes of tir were identified by PCR analysis of the AEEC isolates from diarrhoeic Korean pigs. The prevalence of tir subtypes in E coli from the preweaned pigs was similar to that from the postweaned pigs. Fourteen of the isolates could not be typed because they did not react with the PCR primers used in this study. These results suggest that some eae-positive E coli may possess another unique subtype or may have different sequences in their subtypes that prevent their recognition by PCR.

All the AEEC strains used in this study were isolated from the ileum, because all the samples were submitted for the

Veterinary Record (2008) 163, 424-425

\section{Y. Ha, DVM,}

S. K. Ha, DVM, MS,

Y. H. Lee, DVM,

D. Kim, DVM,

S. Chae, DVM,

C. H. Kim, DVM,

K. K. Ahn, DVM, MS,

C. Chae, DVM, MS, PhD,

Department of Veterinary

Pathology, College of

Veterinary Medicine,

Seoul National University, San 56-1, Shillim-Dong,

Gwanak-Gu, Seoul,

151-742, Republic of

Korea

O. Kim, DVM, MS, PhD, College of Life Science and Natural Resources, Wonkwang University, 344-2 Shinyoung-Dong San, Iksan, Republic of Korea

Correspondence to Dr Chae

TABLE 2: Prevalence of tir gene subtypes from attaching and effacing Escherichia coli isolates from pigs with diarrhoea

\begin{tabular}{lccccccc} 
Pigs & $\begin{array}{c}\text { eae gene } \\
\text { subtype }\end{array}$ & $\begin{array}{c}\text { Number of } \\
\text { samples }\end{array}$ & $\alpha$ & $\beta$ & $\gamma$ & $\theta$ & NT \\
\hline Preweaned & $\beta$ & 19 & 4 & 2 & 1 & 8 & 4 \\
& $\gamma$ & 12 & 1 & 2 & 2 & 3 & 4 \\
& $\varepsilon$ & 4 & 1 & 1 & 1 & 0 & 1 \\
Postweaned & NT & 3 & 0 & 0 & 1 & 1 & 1 \\
& $\beta$ & 10 & 3 & 0 & 0 & 6 & 1 \\
& $\gamma$ & 5 & 2 & 2 & 1 & 0 & 0 \\
& $\varepsilon$ & 2 & 0 & 0 & 0 & 0 & 2 \\
& $\zeta$ & 1 & 0 & 0 & 0 & 1 & 0 \\
& NT & 3 & 0 & 0 & 0 & 2 & 1 \\
\hline
\end{tabular}

NT Non-typable 
diagnosis of diarrhoea and ileal samples are usually collected for routine diagnostic procedures at the authors' diagnostic centre. Different intimin types have been shown to be an important factor for the initial tissue tropism of the bacteria in the host (Fitzhenry and others 2002). E coli 0157 produces $\gamma$-intimin and is considered to have a tropism toward the distal gastrointestinal tract, while $E$ coli $\mathrm{O} 26$ produces $\beta$-intimin and is considered to have a tropism toward the proximal gastrointestinal tract (Caprioli and others 2005). Therefore, $\beta$-intimin has a tropism for the ileum, and this may explain the high prevalence of isolates bearing the gene for $\beta$-intimin $\left(e a e_{\beta}\right)$ in the present study.

AEEC strains are classified as either enteropathogenic or enterohaemorrhagic $E$ coli depending on their ability to produce Shiga toxin (Nataro and Kaper 1998). Since all the eae-positive $E$ coli examined in this study were negative for the Shiga toxin gene, all the strains studied could be enteropathogenic. A total of 10 AEEC strains were serotyped in this study; four were serogroup, O127, three were serogroup O26, two were serogroup O111 and one could not be serogrouped. Intestinal tropism is species-independent, at least between human and porcine intestinal tissues (Fitzhenry and others 2003). Therefore, pigs may be an important reservoir of AEEC strains that are responsible for $E$ coli-associated diarrhoea in human beings.

\section{ACKNOWLEDGEMENTS}

This research was supported by contract research funds of the Research Institute for Veterinary Science (RIVS) from the College of Veterinary Medicine, Seoul National University, and Brain Korea 21 Program for Veterinary Science, Republic of Korea.

\section{References}

ANON (2001) 2000 report of the AVMA Panel on Euthanasia. Journal of the American Veterinary Medical Association 218, 669-696

ADU-BOBIE, J., FRANKEL, G., BAIN, C., GONCALVES, A. G., TRABULSI, L. R., DOUCE, G., KNUTTON, S. \& DOUGAN, G. (1998) Detection of intimins $\alpha, \beta, \gamma$, and $\delta$, four intimin derivatives expressed by attaching and effacing microbial pathogens. Journal of Clinical Microbiology 36, 662-668

AGIN, T. S. \& WOLF, M. K. (1997) Identification of a family of intimins common to Escherichia coli causing attaching-effacing lesions in rabbits, humans, and swine. Infection and Immunity 65, 320-326

CAPRIOLI, A. S., MORABITO, S., BRUGERE, H. \& OSWALD, E. (2005) Enterohaemorrhagic Escherichia coli: emerging issues on virulence and modes of transmission. Veterinary Research 36, 289-311

CHINA, B., GOFFAUX, F., PIRSON, V. \& MAINIL, J. (1999) Comparison of $e a e, t i r, \operatorname{esp} A$ and $\operatorname{esp} B$ genes of bovine and human attaching and effacing Escherichia coli by multiplex polymerase chain reaction. FEMS Microbiology Letters 178, 177-182

FITZHENRY, R. J., PICKARD, D. J., HARTLAND, E. I., REECE, S., DOUGAN, G., PHILLIPS, A. D. \& FRANKEL, G. (2002) Intimin type influences the site of human intestinal mucosal colonization by enterohemorrhagic Escherichia coli O157:H7. Gut 50, 180-185

FRANKEL, G., CANDY, D. C. A., EVEREST, P. \& DOUGAN, G. (1994) Characterization of the $\mathrm{C}$-terminal domains of intimin-like proteins of enteropathogenic and enterohemorrhagic Escherichia coli, Citrobacter freundii, and Hafnia alvei. Infection and Immunity 62, 1835-1842

GARRIDO, P., BLANCO, M., MOREZO-PAZ, M., BRIONES, C., DAHBI, G., BLANCO, J., BLANCO, J. \& PARRO, V. (2006) STEC-EPEC oligonucleotide microarray: a new tool for typing genetic variants of the LEE pathogenicity island of human and animal Shiga toxin-producing Escherichia coli (STEC) and enteropathogenic E coli (EPEC) strains. Clinical Chemistry 52, 192-201

GOFFAUX, F., CHINA, B., JANSSEN, L. \& MAINIL, J. (2000) Genotypic characterization of enteropathogenic Escherichia coli (EPEC) isolated in Belgium from dogs and cats. Research in Microbiology 151, 865-871

HA, S-K., HONG, K., CHOI, C., JUNG, K., HA, Y., KIM, J., KIM, S. H., YOON B. \& CHAE, C. (2004) Polymerase chain reaction analysis of eae gene subtype present in attaching and effacing Escherichia coli isolated from pigs with diarrhea. Journal of Veterinary Diagnostic Investigation 16, 576-578

JERSE, A. E. \& KAPER, J. B. (1991) The eae gene of enteropathogenic Escherichia coli encodes a 94-kilodalton membrane protein, the expression of which is influenced by the EAF plasmid. Infection and Immunity 59, 4302-4309

JERSE, A. E., YU, J., TALL, B. D. \& KAPER J. B. (1990) A genetic locus of enteropathogenic Escherichia coli necessary for the production of attaching and effacing lesions on tissue culture cells. Proceedings of the National Academy of Sciences of the United States of America 87, 7839-7843

KENNY, B., DEVINNEY, R., STEIN, M., REINSCHEID, D. J., FREY, E. A. \& FINLAY, B. B. (1997) Enteropathogenic E coli (EPEC) transfers its receptor for intimate adherence into mammalian cells. Cell 91, 511-520

KONG, R. Y. C., SO, C. L., LAW, W. F. \& WU, R. S. S. (1999) A sensitive and versatile multiplex PCR system for the rapid detection of enterotoxigenic (ETEC), enterohaemorrhagic (EHEC) and enteropathogenic (EPEC) strains of Escherichia coli. Marine Pollution Bulletin 38, 1207-1215

LIU, H., RADHAKRISHNAN, P., MAGOUN, L., PRABU, M., CAMPELLONE, K. G., SAVAGE, P., HE, F., SCHIFFER, C. A. \& LEONG, J. M. (2002) Point mutants of EHEC intimin that diminish Tir recognition and actin pedestal formation highlight a putative Tir binding pocket. Molecular Microbiology 45, 1557-1573

MOON, H. W., WHIPP, S. C., ARGENZIO, R. A., LEVINE, M. M. \& GIANNELLA, R. A. (1983) Attaching and effacing activities of rabbit and human enteropathogenic Escherichia coli in pig and rabbit intestines. Infection and Immunity 41, 1340-1351

NATARO, J. P. \& KAPER, J. B. (1998) Diarrheagenic Escherichia coli. Clinical Microbiology Reviews 11, 142-201

NIELSEN, E. M. \& ANDERSEN, M. T. (2003) Detection and characterization of verocytotoxin-producing Escherichia coli by automated 5' nuclease PCR assay. Journal of Clinical Microbiology 41, 2884-2893

OSWALD, E., SCHMIDT, H., MORABITO, S., KARCH, H., MARCHES, O. \& CAPRIOLI, A. (2000) Typing of intimin genes in human and animal enterohemorrhagic and enteropathogenic Escherichia coli: characterization of a new intimin variant. Infection and Immunity 68, 64-71

ZHANG, W. L., KOHLER, B., OSWALD, E., BEUTIN, L., KARCH, H. MORABITO, S., CAPRIOLI, A., SUERBAUM, S. \& SCHMIDT, H. (2002) Genetic diversity of intimin genes of attaching and effacing Escherichia coli strains. Journal of Clinical Microbiology 40, 4486-4492

ZHU, C., HAREL, J., JACQUES, M., DESAUTELS, C., DONNENBERG, M. S. BEAUDRY, M. \& FAIRBROTHER, J. M. (1994) Virulence properties and attaching-effacing activity of Escherichia coli $\mathrm{O} 45$ from swine postweaning diarrhea. Infection and Immunity 62, 4153-4159 